Jurnal Basicedu Volume 4 Nomor 2 April 2020 Hal. 314-326

JURNAL BASICEDU

Research \& Learning in Elementary Education

https://jbasic.org/index.php/basicedu

\title{
Pengembangan Media Pembelajaran Kereta Membaca Berbasis Kontekstual Learning Siswa Sekolah Dasar
}

\author{
Shinta Herliana ${ }^{1}$, Indri Anugraheni ${ }^{2}$ \\ Universitas Kristen Satya Wacana, Jawa Tengah, Indonesia \\ Email: shintaherliana0@gmail.com ${ }^{1}$, indri.anugraheni@uksw.edu 2 ,
}

\begin{abstract}
Abstrak
Penelitian ini bertujuan untuk mengetahui pengembangan media pembelajaran kereta membaca untuk meningkatkan literasi berbasis kontekstual learning siswa kelas 1 SD. Penelitian ini dilaksanakan di SD N Ledok 06 Salatiga dengan sampel penelitian sebanyak 13 siswa. Penelitian ini menggunakan model pengembangan ASSURE Model dengan 6 tahapan yaitu, Analyze Learner, State Objective, Select Method, media or materials, Utilize Media and Materials, Require Learned Participation, dan Evaluate and Revise teknik analisis data kualitatif dan kuantitatif. Teknik pengumpulan data dalam penelitian ini menggunakan wawancara, observasi, dan angket. Hasil dari uji validator yang diperoleh dari ahli materi mendapatkan kelayakan sebesar $100 \%$ yang berkategori sangat layak, dari ahli media mendapatkan kelayakan sebesar 97\% dan mendapatkan kategori sangat layak, dari ahli praktisi mendapatkan kelayakan materi sebesar 73\% dan media sebesar $75 \%$ dengan kategori layak untuk digunakan. Hasil penelitian menunjukkan bahwa pengembangan media kereta membaca terbukti layak untuk digunakan dalam pembelajaran di kelas 1 SD.
\end{abstract}

Kata Kunci: Media Pembelajaran, Kontekstual Learning, Kartu Kata

\begin{abstract}
This study aims to determine the development of learning media "reading train" to improve literacy based on contextual learning in grade 1 elementary school students. This research was conducted at SDN Ledok 06 Salatiga with research samples of 13 students. This research uses the ASSURE development model with six stages, namely Analyze Learner, State Objective, Select Method, media or materials, Utilize Media and Materials, Require Learner Participation, and Evaluate and Revise qualitative and quantitative data analysis techniques. Data collection techniques used in this study are interviews, observation, and questionnaires. The results of the validator test obtained from material experts get $100 \%$ eligibility, which is considered very feasible, from media experts get $97 \%$ eligibility and get a very decent category, from expert practitioners, get $73 \%$ material worth, and $75 \%$ media with proper category to use. The results showed that the development of the reading train media was proved to be suitable for use in grade 1 to grade learning
\end{abstract}

Keywords: Learning Media, Contextual Learning, Flashcard

@ Jurnal Basicedu 2020

Corresponding author :

Address : -

ISSN 2580-3735 (Media Cetak)

Email :-

ISSN 2580-1147 (Media Online)

Phone :- 
315 Pengembangan Media Pembelajaran Kereta Membaca Berbasis Kontekstual Learning Siswa Sekolah Dasar - Shinta Herliana, Indri Anugraheni

\section{PENDAHULUAN}

Pendidikan merupakan salah satu sarana untuk menunjang sumber daya manusia yang mempunyai prestasi dan sumber daya manusia yang berkualitas. Untuk mendapatkan sumber daya manusia yang berprestasi dan berkualitas salah satu faktor penyebabnya adalah mutu pendidikan yang berkualitas pula. Dalam dunia pendidikan guru merupakan fasilitator yang sangat penting untuk menjadikan peserta didik mengetahui pengetahuan dan informasi, guru adalah seorang yang dapat di gugu dan ditiru, peran guru di dunia pendidikan tidaklah hmudah, guru tidak hanya dapat menyalurakan pengetahuan tetapi guru juga dituntut untuk dapat memberikan kemajuan dibidang pendidikan, hal ini juga tertuang dalam Undang - undang. Menurut UU Guru dan Dosen Nomor 14 tahun 2005 Pasal 8 bahwa Guru wajib memiliki kualifikasi akademik, kompetensi, sertifikasi pendidik, sehat jasmani dan rohani, serta memiliki kemampuan untuk memwujudkan tujuan pendidikan nasional". Dalam kompetensi yang dimaksud adalah guru dituntut untuk mampu mengembangkan potensi diri untuk menjadikan pembelajaran yang menarik, aktif dan inovatif. Termasuk didalamnya pendidik harus bisa meningkatkan ketrampilan berbahasa, berbahasa yang berarti bahwa manusia sangat membutuhkan ketrampilan berbahasa untuk dapat berkomunikasi dengan orang lain

Manusia adalah makhluk sosial yang tidak bisa hidup sendiri, hal ini berarti semua manusia tidak dapat dipisahkan antara satu dengan yang lainnya, manusia berinteraksi melalui bahasa. Bahasa merupakan suatu sistem simbol yang teratur yang berguna untuk menyampaikan atau menyalurakan informasi atau ide yang terdiri dari simbol - simbol visual maupun verbal (Fridani, Lara; Dhieni, 2014: 28) Dalam berbahasa anak anak dapat memanipulasi simbol dengan cara sesuai degan tingkat kemampuan berpikir masing - masing. Di setiap negara tentunya mempunyai bahasa yang digunakan sebagai bahasa pemersatu bangsa, seperti halnya Indonesia yang menggunakan bahasa indonesia sebagai bahasa persatuan dalam bermasyarakat maupun di lingkungan sekolah. Di lingkungan sekolah siswa akan diberikan pengetahuan dasar yang harus dikuasai tentang membaca, menulis dan menghitung. Ketrampilan membaca sangat penting untuk kehidupan manusia, karena dalam setiap aspek kehidupan akan selalu berkaitan dengan kegiatan membaca. Ketrampilan membaca ini dapat diperoleh dari berbagai sumber, umumnya dapat diperoleh dari belajar di sekolah, ketrampilan membaca ini merupakan hal yang unik karena tidak semua orang dapat membaca dengan baik. Menurut Hodgson dalam Indrayani, desy, dkk (2019: 529) berpendapat bahwa Membaca merupakan suatu proses yang digunakan untuk menerima uatu pesan, yang akan disampaikan oleh penulis. (Desi Indriyani1, Desyandri2, Yanti Fitria3, 2019)

Fenomena yang terjadi sekarang mengenai pertumbuhan siswa yang terus berkembang mengakibatkan adanya bermacam - macam karakteristik siswa yang berbeda dengan satu dan lainnya dalam hal kemampuan membaca atau dikenal dengan literasi, hal tersebut tergantung dari seberapa besar kemampuan membaca yang diperoleh dari lingkungan rumah mereka. Di lingkungan sekolah terdapat bermacam - macam karakteristik siswa dalam kemampuan literasinya. Salah satu penyebab rendahnya kemampuan membaca atau literasi siswa sekolah dasar ini mereka lebih banyak mendapatkan pelajaran untuk menghafal daripada praktik langsung. Dalam pembelajaran yang terjadi atau berlangsung di dalam kelas, kegiatan membaca ini dapat melibatkan beberapa faktor, faktor ini antara lain 


\section{Pengembangan Media Pembelajaran Kereta Membaca Berbasis Kontekstual Learning Siswa Sekolah Dasar - Shinta Herliana, Indri Anugraheni}

adalah faktor peserta didik, pendidik metode, model dan bahan ajar yang digunakan untuk mengajar.

Media pembelajaran mempunyai arti yaitu sebuah bahan atau alat yang dapat digunakan untuk menyampaikan pesan kepada peserta didik, dalam rangka untuk mengefektifkan komunikasi antara guru dan peserta didik dalam proses pembelajaran di kelas. Peran pendidikan dalam kegiatan pembelajaran di sekolah adalah membimbing, menunjukkan, menyediakan dan memotivasi peserta didik agar dapat belajar dengan berbagai sumber belajar yang ada. Bukan hanya sumber belajar yang bersifat abstrak tetapi juga media yang bersifat konkret yang dapat dilihat, dan juga diraba. Nurseto, (2012: 20), Menurut (Mudlofir, Rusidiyah E F, 2016: 124) Media pembelajaran yaitu sebagai perantara untuk pengantar pesan dari penerima dan pengirim sebagai motivasi untuk kegiatan pembelajaran sehingga mendapatkan hasil belajar yang memuaskan. Hal ini relevan dengan penelitian yang dilakukan oleh Anugraheni perangkat adalah alat atau media yang dapat digunakan untuk mencapai suatu tujuan yang diharapkan. Anugraheni, (2018: 35 )

Proses pembelajaran dengan menggunakan sumber belajar bermacam - macam, ceramah adalah salah satu contoh dari sumber belajar, namun belajar dengan menggunakan metode ceramah saja hasilnya tidak akan efektif karena siswanya kurang aktif dalam mendengarkan ceramah yan diberikan oleh guru. Belajar dapat efektif apabila siswa juga terjun langsung dalam artian siswa juga ikut melakukan sesuatu dalam proses pembelajaran. Media pembelajaran dapat dikelompokkan melalui bentuk penyajiannya yaitu bahan cetak, media proyeksi, audio, audio visual, media televisi dan media multi media. Proses membaca yang dilakukan di kelas rendah dapat dilakukan dengan berbagai teknik atau metode, proses kegitan pembelajaran juga dapat dikemas dengan menggunakan berbagai media yang menarik perhatian dan dapat menyenangkan bagi siswa dan juga tentunya dapat diterima dengan mudah oleh siswa, terutama pada kelas 1 yang merupakan kelas rendah. Penggunaan media yang digunakan pada kelas satu atau kelas rendah dapat menggunakan media yang bersifat konkret atau nyata dan dapat ditemui di lingkungan sekitar akan lebih mudah diterima dan dipahami oleh siswa.

Penggunaan media yang bersifat nyata atau konkret pada jenjang pendidikan dasar khususnya kelas 1 merupakan salah satu kegiatan pembelajaran yang efektif untuk menbimbing siswa secara tidak langsung untuk menghubungkan materi dengan dunia nyata siswa atau kontekstul learning, menurut (Sanjaya, 2006: 109) kontekstual learning adalah proses kegiatan belajar mengajar yang melibatkan siswa secara penuh untuk dapat belajar menggunakan materi dan menghubungkannya dengan situasi dan kondisi kehidupan nyata sehingga mendorong siswa untuk dapat menerapkannya dalam kehidupan siswa. Menurut (Panjaitan, 2016: 83) Kontekstual learning adalah suatu strategi yang dapat membantu guru untuk dapat menghubungkan materi pembelajaran dengan kondisi nyata siswa dan dapat menerapkan dalam kehidupan nyata siswa.

pada umumnya pendidik memiliki pendapat atau presepsi bahwa menyusun bahan ajar atau media pembelajaran merupakan sebuah pekerjaan yang membutuhkan waktu yang cukup lama dan tidak sebentar, karena pendidik juga harus menyiapkan keperluan adminitrasi yang juga menyita waktu, dan juga harus berhadapan dengan alat dan bahan yang digunakan untuk membuat media atau bahan ajar tersebut. Itukah yang menjadikan alasan mengapa sebagian dari 


\section{Pengembangan Media Pembelajaran Kereta Membaca Berbasis Kontekstual Learning Siswa Sekolah Dasar - Shinta Herliana, Indri Anugraheni}

pendidik di Indonesia kurang inovatif dan terkesan monoton dalam mengajarkan pelajaran dikelas, pendidik lebih banyak menggunakan buku - buku yang ada di perpustakaan dan menggunakannya secara berulang dan terus menerus yang menjadikan peserta didik terkesan lebih cepat bosan dan tidak menyukai pelajaran yang diberikan oleh pendidik. Hal ini harus segera diluruskan seiring dengan perkembangan teknologi yang semakin pesat, pendidik harus dapat membuang dan mengganti presepsi bahwa membuat bahan ajar adalah kegiatan yang kurang praktis dan memerlukan waktu yang cukup lama, sebagai pendidik yang profesional harusnya dapat mengubah presepsi - presepsi itu dengan menjadikan presepsi yang salah menjadi tantangan yang harus dihadai oleh pendidik. Khususnya dalam menanamkan konsep membaca kepada peserta didik pada sekolah dasar Fahyuni \& Bandono, (2015: 3-5)

Salah satu contoh media visual adalah flashcard, flashcard merupakan sebuah kartu kecil yang didalamnya terdapat sebuah teks, gambar, atau tanda simbol yang dapat mengingatkan dan bisa menuntun siswa kepada sesuatu yang berkaitan dengan gambar yang terdapat dalam kartu tersebut. (Rahman \& Haryanto, 2014), Menurut (Jaruki, 2008: 6) Kartu kata bergambar merupakan sebuah kartu yang berisi kata dan terdapat gambar didalamnya, sehingga kartu kata tersebut mewakili sebuah kata yang ada pada gambar tersebut. adapun kelebihan flashcard ini adalah 1) mudah dibawa kemana - mana, 2) praktis, 3) mudah diingat, 4) menyenangkan. Kekurangan dari media flashcard ini adalah lebih cocok untuk kelompok kecil, dan dalam pembuatan flashcard ini banyak meluangkan waktu untuk mencari gambar - gambarnya. Pemilihan flashcard sebagai salah satu solusi dalam pemecahan masalah ketrampilan membaca yaitu sesuai dengan pendapat Brunner bahwa terdapat tiga tingkatan utama modus belajar yaitu yang pertama pengalaman secara langsung, yang kedua pengalaman gambar, dan pengalaman abstrak. Hal ini mengandung arti bahwa siswa akan lebih mudah untuk belajar secara konkret atau nyata. Dalam membangun kebiasaan membaca dengan media kereta membaca dan menggunakan flashcard didalamnya diharapkan dapat menumbuhkan kebiasaan membaca siswa SD kelas 1.

Belajar dengan benda - benda disekitar adalah hal yang paling mudah untuk dipahami, siswa yang masuk ke jenjang sekolah dasar umumnya berumur 7 - 12 tahun, Menurut Piaget dalam (Mua wanah E \& Hidayah R, 2009: 7) dalam masa ini potensi siswa harus didorong sehingga dapat berkembang secara maksimal, hal ini sejalan dengan pendapat Sandra levey dan Susan Polisrstok yang berpendapat setelah siswa masuk ke sekolah khususnya kelas 1 sekolah dasar, kemampuan dalam berbahasa juga harus dikembangkan, seperti kemampuan mengembangkan kemampuan membaca, mengembangkan kosakata, dan menulis. Kontekstual leraning dapat diartikan kegiatan yang dapat dilakukan dengan benda - benda yang berada di sekitar lingkungan sekitar baik itu lingkungan rumah maupun lingkungan sekolah Komalasari, (2010: 7) Proses pembelajaran yang menggunakan lingkungan sekitar sebagai media belajar dapat memberikan kesan dan pengalaman kepada peserta didik sehingga peserta didik akan lebih mudah memahami dan meninggat materi.

Dari hasil pengamatan dan wawancara yang dilakukan di SD N Ledok 06 Salatiga yang dilakukan pada bulan september sampai dengan bulan november 2019 bahwa ketrampilan membaca kelas 1 dapat dikatakan masih rendah, hal ini terlihat dari proses pembelajaran di kelas 1 
318 Pengembangan Media Pembelajaran Kereta Membaca Berbasis Kontekstual Learning Siswa Sekolah Dasar - Shinta Herliana, Indri Anugraheni

dan terdapat 9 dari 15 siswa yang mengalami kesulitan dalam hal ketrampilan membaca, dari wawancara yang di lakukan kepada guru kelas 1 SD N Ledok 06 Salatiga diketahui bahwa peserta didik kelas 1 SD belum semua bisa membaca, hal tersebut merupakan tantangan bagi pendidik yang mengampu kelas 1. Pendidik harus mempunyai strategi untuk mengajarkan membaca, karena membaca merupakan ketrampilan dasar untuk dapat lancar dalam mengikuti pelajaran yang lainnya, namun kenyataan dilapangan adalah kurangnya bahan ajar yang digunakan oleh pendidik untuk mengajarkan membaca atau pembiasaan literasi. Permasalahan yang terjadi pada siswa kelas 1 SDN Ledok 06 Salatiga harus segera diselesaikan dan diberikan solusi sehingga dapat mempermudah proses pembelajaran pada tahap berikutnya.

Dari pemaparan permasalahan diatas, pendidik harus mampu menciptakan bahan ajar atau media pembelajaran yang mampu membuat siswa tertarik untuk mengikuti pembelajaran dan dapat menumbuhkan minat siswa untuk dapat malakukan pembiasaan membaca. Pengembangan media pembelajaran berbasis kontekstual learning ini siswa kelas 1 SD merupakan salah satu solusi untuk meningkatkan membaca kepada peserta didik kelas rendah khususnya kelas 1 SD yang baru masuk ke tahap pendidikan sekolah dasar setelah sebelumnya menempuh pendidikan taman kanak - kanak yang masih belajar dan bermain. Peserta didik yang baru masuk ke jenjang sekolah dasar mayoritas masih membawa kebiasaan atau budaya yang mereka terima di taman kanak -kanak dengan masih belajar dan bermain, mengenal warna, dan berbagai permainan lainnya. Dalam pengembangan bahan ajar kereta membaca ini sesuai dengan tahap perkembangan peserta didik siswa pada usia 7 tahun yang masih belajar dan bermain dengan menggunakan warna warna yang menarik dan media pembelajaran yang unik, mereka belum tertarik dengan menggunakan media seperti buku yang banyak tulisan dan terkesan monoton. Sehingga peserta didik lebih antusias dan tertarik untuk mengikuti pelajaran dan akan menumbuhkan kebiasaan membaca.

\section{METODE}

Penelitian ini mneggunakan jenis penelitian dan pengembangan yang menggunakan model pengembangan Borg and Gall yang telah dimodifikasi oleh Sukmadinata yang terdiri dari 3 tahapan, yang pertama yaitu studi pendahuluan, pengembangan produk dan uji produk. Tahap pertama yaitu studi pendahuluan yang mengkaji teori - teori dan menggali kebutuhan yang ada disekolah, tahap perancangan media dan melakukan uji validator. Model penelitian yang digunakan peneliti dalam penelitian ini yaitu model ASSURE. Menurut (Pribadi, 2011) desain pembelajaran menggunakan ASSURE Model dirancang dan dikembangkan untuk dapat menciptakan aktivitas pembelajaran yang efisien dan efektif. Model ASSURE mempunyai 6 tahapan yaitu, yaitu, Analyze Learner, State Objective, Select Method, media or materials, Utilizee Media and Materials, Require Learned Participation, dan Evaluate and Revise (Smaldino, 2011) Berikut tahapan dari ASSURE Model 


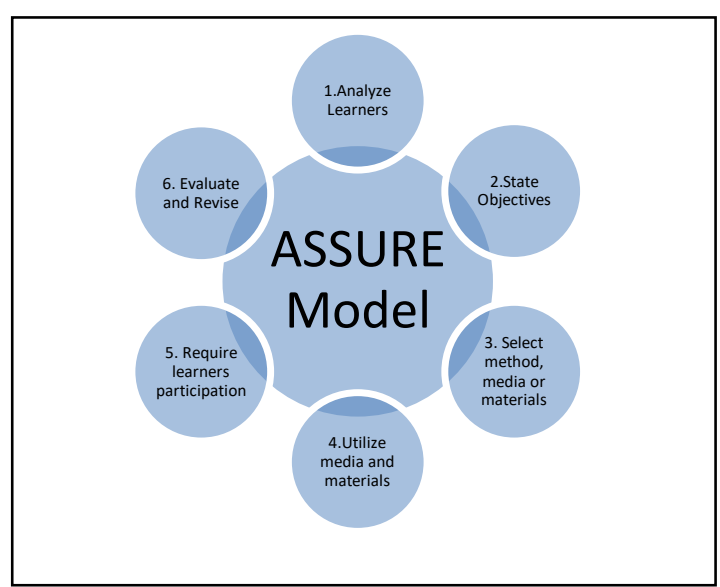

\section{Gambar 1 Tahapan ASSURE Model}

Pengembangan yang akan dilakukan pada penelitian ini yaitu mengembangkan media pembelajaran kereta membaca berbasis kontekstual learning siswa kelas 1 SD. Penelitian ini menggunakan teknik analisis data kualitatif dan kuantitatif berupa presentase. Data kualitatif ini diperoleh dari validasi ahli materi pembelajaran, ahli media pembelajaran dan ahli praktisi (guru) yang berupa masukan dan saran untuk melakukan revisi terhadap pengembangan media kereta membaca. Sedangkan untuk data kuantitatif digunakan untuk pos test dan pre test yang dilakukan oleh siswa kelas 1 SD sebelum dan sesudah menggunakan media kereta membaca. Teknik tersebut digunakan untuk mengetahui penilaian responden terhadap media pembelajaran kereta membaca berbasis kontekstual learning siswa kelas 1 SD yang dipresentasikan ke dalam bentuk presentase.

\section{HASIL DAN PEMBAHASAN}

Hasil penelitian tentang pengembangan media pembelajaran kereta membaca berbasis kontekstual learning siswa kelas 1 SD N Ledok 06 Salatiga. Berikut penjelasan dari hasil penelitian yang dikembangkan menggunakan model ASSURE.
Analyse Learners dalam Tahap pertama adalah tahapan analisis terdapat beberapa analisis antara lain adaah menganalisis karakter siswa yang dilakukan dengan teknik wawancara yang dilakukan terhadap guru kelas 1 di SD N Ledok 06 Salatiga, mendapatkan informasi bahwa peserta didik yang mengikuti pendidikan di SD tersebut adalah peserta didik yang berumur 7 tahun. Rata rata usia orang tua peserta didik adalah 25 sampai dengan 45 tahun yang mayoritas bekerja sebagai buruh pabrik, buruh bangunan, dan pedagang. Peserta didik yang mayoritas memiliki latar belakang orang tua sebagai buruh pabrik dan buruh bangunan yang sehari - harinya sudah disibukkan dengan pekerjaan masing - masing membuat orang tua peserta didik kurang mendukung dalam hal pembalajaran di lingkungan rumah, orang tua memiliki pandangan bahwa anak mereka sudah dititipkan di sekolah dan sedikit sekali yang peduli tentang pendidikan dirumah, hal ini terbukti setelah melakukan wawancara kepada guru kelas 1, bahwa peserta didik sering diberi tugas rumah tetapi pekerjaan ruah tersebut tidak dikerjakan. Tetapi ada juga orang tua yang sudah peduli tentang Pendidikan dirumah dengan cara memberikan fasilitas tambahan bimbingan belajar. Orang tua juga menyampaikan keluhan kepada guru bahwa anak yang belajar dirumah mempunyai banyak alasan untuk tidak mau belajar, lebih senang untuk belajar di rumah.

Analisis yang kedua adalah menganalisis kemampuan awal siswa di SDN Ledok 06 Salatiga dengan melakukan pretest. Pretest dilakukan di kelas 1 SD N Ledok 06 Salatiga. Dari hasil pretest yang dilakukan diperoleh data ketrampilan membaca yang dimiliki peserta didik kelas 1 SD N Ledok 06 Salatiga memperoleh rata - rata 33,93\% dari kelima aspek, aspek tersebut adalah aspek ketepatan, lafal, intonasi, kelancaran, dan kejelasan 
320 Pengembangan Media Pembelajaran Kereta Membaca Berbasis Kontekstual Learning Siswa Sekolah Dasar - Shinta Herliana, Indri Anugraheni

suara, dari beberapa aspek itu terlihat siswa belum memperhatikan aspek intonasi dan aspek kelancaran dalam ketrampilan membaca yang mendapatkan angka presentase sebesar $32 \%$.

\section{State Objectives (Menentukan tujuan} pembelajaran ) Setelah melakukan analisis terhadap kebutuhan di SD selanjutnya menentukan tujuan, tujuannya yaitu agar siswa dapat membaca dengan lancar untuk menunjang kebehasilan mengikuti pembelajaan di tingkat selanjutnya.

Select Method, Media or Materials (Memilih metode, media dan bahan ajar ) Keberhasilan dari membaca juga dipengaruhi oleh penggunaan media pembelajaran, oleh karena itu dalam hal ini diperlukan strategi untuk membuat peserta didik lebih bersemangat mengikuti proses pembelajaran membaca dengan pemilihan metode dan media yang tepat metode yang digunakan adalah menggunakan metode ceramah, simuslasi dan tanya jawab. Metode ceramah merupakan metodologi pembelajaran yang cara penyampaiannya dengan cara lisan metode ini lebih efektif digunakan di kelas rendah terutama di kelas 1 yang karakter peserta didiknya masih dalam tahap operasional kongkret yang masih sangat diperlukan bimbingan secara terus menerus. Penyusunan media kereta membaca ini menggunakan aplikasi corel draw yang digunakan untuk membuat design dari media kereta membaca ini. Tampilan dari keseluruhan kereta membaca yang memiliki 8 gerbong dan dalam setiap gerbong memiliki isi flashcard yang berbeda beda. Tampilan dari setiap gerbong dapat di ubah ubah sesuai dengan keinginan dengan cara membalikkan flashcard. Dalam penggunaan dari media kereta membaca ini dapat dilakukan secara bertahap - mulai dari gebong pertama sampai dengan gerbong terakhir, berikut tampilan dari kereta membaca :

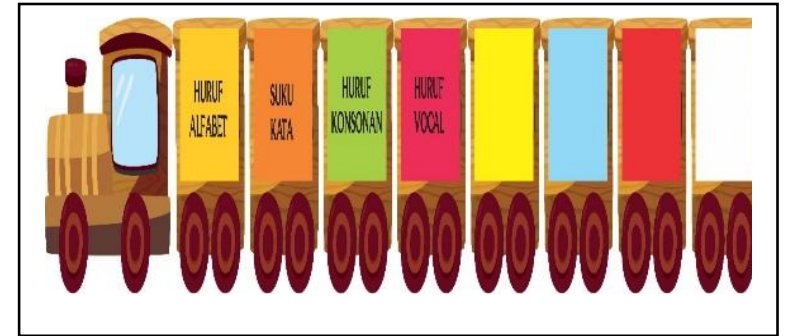

Gambar 2 Tampilan Draft Keseluruhan Media Kereta Membaca

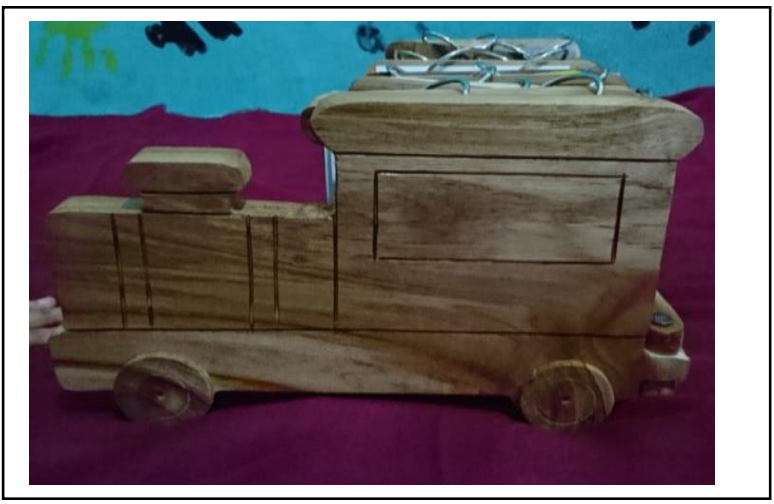

Gambar 3 Tampilan Media Kereta Membaca

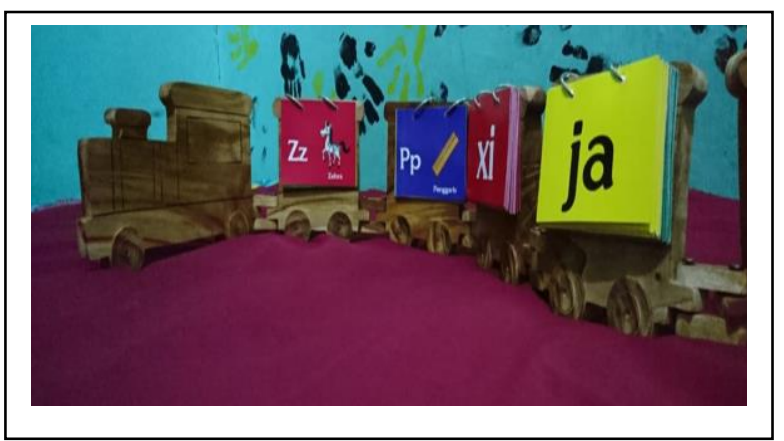

Gambar 4 Tampilan Depan Media Kereta

Membaca

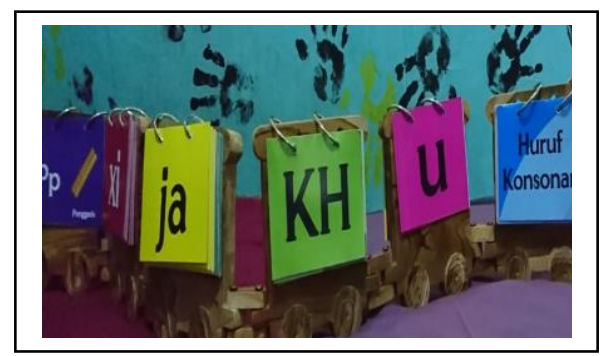

Gambar 5 Tampilan Belakang Media Kereta membaca 
321 Pengembangan Media Pembelajaran Kereta Membaca Berbasis Kontekstual Learning Siswa Sekolah Dasar - Shinta Herliana, Indri Anugraheni

Tahapan selanjutnya adalah Utilize Media and Materials (Memanfaatkan media dan bahan ajar) Media kereta membaca ini selanjutnya akan digunakan untuk kegiatan literasi selama 15 menit sebelum pembelajaran, media pembelajaran kereta membaca dapat digunakan setiap hari selama proses kegiatan membaca untuk meningkatkan siswa dalam membaca. Guru dapat mengubah dan mengganti kartu huruf sesuai dengan kreatifitas masing - masing guru.

Tahap kelima dalam model ASSURE adalah Require Learner Particpation (Melibatkan Siswa dalam Kegiatan Pembelajaran) Dalam kegiatan literasi 15 menit sebelum pembelajaran, guru melibatkan siswa dalam proses kegiatan membaca dengan membentuk siswa kedalam beberapa kelompok yang nantinya siswa akan berkelompok untuk melaksanakan kegiatan literasi dan menjawab pertanyaan dari guru.

\section{Evaluate and Revise (Evaluasi dan revisi)} Setelah membuat draft kereta membaca kemudin melakukan uji ahli materi, media, dan praktisi dan mendapatkan masukan dan saran dai ketiga ahli tersebut, kemudian peneliti melakukan revisi produk media kereta membaca sesuai saran yang telah diberikan Berikut hasil uji validasi dari beberapa ahli

\section{Validasi Media Pembelajaran Kereta} Membaca Setelah media pembelajaran kereta membaca berbasis kontekstual learning dibuat, selanjutnya media kereta membaca akan di uji validitas oleh ahli materi, media dan praktisi. Draft awal media kereta membaca yang sudah jadi, selanjutnya akan diujikan ke pakar untuk diuji kelayakannya. Peneliti menggunakan 3 pakar yaitu pakar media, pakar materi dan pakar praktisi. Kedua pakar tersebut merupakan dosen FKIP UKSW dan Guru kelas 1 SDN Ledok 06 Salatiga.
Draft awal media diserahkan kepada pakar materi pada tanggal 04 Februari 2020 dan langsung mendapatkan balikan. Setelah mendapatkan balikan dari pakar materi, peneliti kemudian merevisi sesuai dengan saran yan diberikan oleh validasi ahli materi. Kemudian untuk pakar media akan di validasi oleh dosen progdi UKSW selaku ahli media pada tanggal 04 Februari 2020 dan langsung mendapatkan balikan. Setelah mendapatkan balikan dari pakar media, peneliti kemudian merevisi sesuai dengan saran yang telah diberikan oleh validasi ahli media. Sedangkan pakar praktisi yang dimintai tolong untuk mereview adalah guru kelas 1 di SDN Ledok 06 Salatiga pada tanggal 22 Januari 2020 dan mendapatkan balikan pada tanggal 28 Januari 2020. Berikut tabel hasil uji validator dari ketiga ahli.

Hasil validasi dari ahli materi kereta membaca Hasil validasi dari pakar materi oleh salah satu dosen bahasa indonesia dan mendapatkan presentase sebesar $100 \%$ dan tergolong dalam interval $81-100 \%$ sehingga termasuk ke dalam kategori sangat tinggi

\begin{tabular}{|c|c|c|c|c|}
\hline \multicolumn{5}{|c|}{ Tabel 2 Presentase Kelayakan dari Ahli } \\
\hline Aspek & $\begin{array}{c}\text { Skor } \\
\text { Ideal }\end{array}$ & $\begin{array}{l}\text { Skor } \\
\text { Aktual }\end{array}$ & $\begin{array}{l}\text { Persentase } \\
\text { Kelayakan }\end{array}$ & Kategori \\
\hline 1 & 15 & 15 & $100 \%$ & $\begin{array}{c}\text { Sangat } \\
\text { Tinggi }\end{array}$ \\
\hline 2 & 20 & 20 & $100 \%$ & $\begin{array}{c}\text { Sangat } \\
\text { Tinggi }\end{array}$ \\
\hline 3 & 15 & 15 & $100 \%$ & $\begin{array}{c}\text { Sangat } \\
\text { Tinggi }\end{array}$ \\
\hline 4 & 10 & 10 & $100 \%$ & $\begin{array}{c}\text { Sangat } \\
\text { Tinggi }\end{array}$ \\
\hline $\begin{array}{l}\text { Rata - rata hasil } \\
\text { validasi ahli materi }\end{array}$ & $100 \%$ & $\begin{array}{c}\text { Sangat } \\
\text { Tinggi }\end{array}$ \\
\hline
\end{tabular}

Dari Tabel 2 menunjukkan bahwa hasil validasi ahli materi terhadap pengembangan media 
322 Pengembangan Media Pembelajaran Kereta Membaca Berbasis Kontekstual Learning Siswa Sekolah Dasar - Shinta Herliana, Indri Anugraheni

kereta membaca berbasis kontekstual learning siswa kelas 1 SD berkategori sangat layak dengan kelayakan sebesar $100 \%$. Aspek yang divalidasi meliputi relevansi, kesesuaian sajian dengan tuntutan pembelajaran yang terpusat pada siswa, cara penyajian, dan keterbacaan dan kekomunikasian. Aspek relevansi memiliki kelayakan sebesar $100 \%$ yang berkategori sangat tinggi. Aspek relevansi ini memiliki 3 indikator yang semuanya diberikan nilai baik yang meliputi 1) Materi relevan dengan kompetensi ang harus dikuasai siswa, 2) Kelengkapan uraian materi sesuai dengan tingkat perkembangan siswa, 3) Jabaran materi cukup memenuhi tuntutan kurikulum (Pelaksanaan literasi sesuai dengan permendikbud) Aspek Kesesuaian sajian dengan tuntutan pembelajaran yang terpusat pada siswa memiliki kelayakan sebesar $100 \%$ yang berkategori sangat tinggi. 4 Indikator yang ada dalam aspek ini mendapatkan nilai sangat baik. Indikator ini meliputi 1) Menyajikan kompetensi yang harus dikuasai siswa. 2) Mendorong keingin tahuan siswa untuk belajar mandiri menggunakan kereta membaca, 3) mendorong terjadinya interaksi siswa dengan sumber belajar kereta membaca, 4) mendorong siswa membangun pengetahuannya sendiri menggunakan kereta membaca. Aspek cara penyajian memiliki kelayakan sebesar $100 \%$ yang berkategori sangat tinggi, Aspek ini memiliki 3 indikator yang mendapatkan nilai sangat baik. Indikator ini meliputi 1) Mendukung cara berpikir logis siswa menggunakan kereta membaca, 2) Ketepatan penggunaan ejaan kata, 3) Ketepatan penggunaan istilah kata. Aspek keterbacaan dan kekomunikasian yang memiliki kelayakan sebesar $100 \%$ yang berketegori sangat tinggi, aspek ini memiliki 2 indikator yang mendapatkan nilai sangat tinggi, indikator tersebut meliputi, 1) Panjang kata sesuai dengan tingkat pemahaman anak. 2) Struktur kata sesuai dengan pemahaman siswa.

Hasil Validasi dari ahli praktisi oleh salah satu dosen PGSD UKSW selaku ahli media mendapatkan kelayakan sebesar $94 \%$ dan berada pada kategori sangat tinggi. Adapun rata - rata presentase hasil kelayakan dan validasi ahli media dapat dilihat pada Tabel 3

Tabel 3 Presentase Kelayakan dari Ahli Media

\begin{tabular}{||l|c|c|c|c||}
\hline Aspek & $\begin{array}{c}\text { Skor } \\
\text { Ideal }\end{array}$ & $\begin{array}{c}\text { Skor } \\
\text { Aktual }\end{array}$ & $\begin{array}{c}\text { Persentase } \\
\text { Kelayakan }\end{array}$ & Kategori \\
\hline 1. & 12 & 11 & $92 \%$ & $\begin{array}{l}\text { Sangat } \\
\text { Tinggi }\end{array}$ \\
\hline 2. & 12 & 12 & $100 \%$ & $\begin{array}{c}\text { Sangat } \\
\text { Tinggi }\end{array}$ \\
\hline 3. & 8 & 8 & $100 \%$ & $\begin{array}{c}\text { Sangat } \\
\text { Tinggi }\end{array}$ \\
\hline 4. & 8 & 7 & $87 \%$ & $\begin{array}{c}\text { Sangat } \\
\text { Tinggi }\end{array}$ \\
\hline 5. & 4 & 4 & $100 \%$ & $\begin{array}{c}\text { Sangat } \\
\text { Tinggi }\end{array}$ \\
\hline 6. & 8 & 8 & $100 \%$ & $\begin{array}{c}\text { Sangat } \\
\text { Tinggi }\end{array}$ \\
\hline 7. & 32 & 29 & $91 \%$ & $\begin{array}{c}\text { Sangat } \\
\text { Tinggi }\end{array}$ \\
\hline Rata - rata hasil \\
validasi ahli materi & $96 \%$ & $\begin{array}{c}\text { Sangat } \\
\text { Tinggi }\end{array}$ \\
\hline
\end{tabular}

Dari tabel 3 menunjukkan hasil validasi dari ahli media terhadap pengembangan media kereta membaca berbasis kontekstual learning siswa kelas 1 SD berkategori sangat tinggi dengan kelayakan sebesar 96\% dari 7 aspek. Aspek yang divalidasi meliputi keterbacaan teks, kualitas gambar, keserasian warna, bentuk tekstur, bahan dan penggunaan media. Aspek Keterbacaan teks dari ahli media termasuk sangat tinggi dengan mendapatkan kelayakan sebesar $92 \%$ dari 3 indikator. 2 Indikator ini mendapatkan penilaian sangat setuju pada butir 1 dan 2 yaitu, ketepatan pemilihan warna, ketepatan pemilihan jenis huruf, 
323 Pengembangan Media Pembelajaran Kereta Membaca Berbasis Kontekstual Learning Siswa Sekolah Dasar - Shinta Herliana, Indri Anugraheni

dan 1 indikator mendapatkan penilaian setuju yaitu indikator butir ke ketepatan pemilihan ukuran huruf . Aspek Kualitas gambar berada pada kategori sangat tinggi dengan kelayakan sebesar $100 \%$ dari 3 indikator. Setiap indikator dalam aspek ini memiliki kriteria sangat tinggi. Indikator ini meliputi 1) Kejelasan bentuk gambar, 2) Ketepatan ukuran gambar, dan 3) Kejelasan warna gambar. Aspek keserasian warna memiliki kategori sangat tinggi dengan presentase $100 \%$, Aspek ini memiliki 2 indikator yang meiputi, 1) ketepatan pemilihan warna pada background, 2) Keserasian warna tulisan dengan warna background. Aspek Bentuk memiliki tingak kelayakan sangat tinggi dengan persentase $87 \%$ dari 2 indikator yang meliputi 1) Ketepatan ukuran kartu kata bergambar, 2) Bentuk fisik kemasan media kereta membaca. Aspek Tekstur dengan kelayakan sangat tinggi dengan presentase $100 \%$ dari 1 indikator yaitu keamanan bentuk permukaan media kartu kata bergambar untuk anak - anak. Aspek Bahan mendapatkan kelayakann sangat tinggi dengan presentase $100 \%$ dari 2 indikator yang meliputi, 1) Ketepatan jenis kertas yang digunakan dalam media kereta membaca, 2) keawetan bahan yang digunakan pada media kereta membaca. Aspek penggunaan media mendapatkan kelayakan sangat tinggi dengan persentase $91 \%$ dari 8 indikator meliputi 1) kejelasan buku petunjuk penggunaan kartu kata bergambar pada media kereta membaca, 2) kesesuaian kartu kata bergambar sebagai sumber belajar, 3) kemampuan kartu kata bergambar untuk dapat menciptakan rasa senang, 4) kemampuan kartu kata bergambar untuk alat bantu memahami dan mengingat informasi, 5) kesesuaian kartu kata bergambar dengan lingkungan belajar, 6) kemudahan, kartu kata bergambar dalam praktik pembelajaran, 7) kualitas kartu kata bergambar, 8) kepraktisan kartu kata bergambar.
Hasil Validasi dari ahli praktisi oleh guru kelas 1 SD, validasi ahli media praktisi dan ahli materi oleh praktisi mendapatkan kelayakan sebesar $75 \%$ dan $68 \%$ dan berada pada kategori tinggi. Adapun rata - rata presentase hasil kelayakan dan validasi ahli praktisi media dapat dilihat pada Tabel 4

Tabel 4 Hasil Presentase Kelayakan Ahli
Praktisi
\begin{tabular}{|l|c|c|c|c|}
\hline Aspek & $\begin{array}{l}\text { Skor } \\
\text { Ideal }\end{array}$ & $\begin{array}{l}\text { Skor } \\
\text { Aktual }\end{array}$ & $\begin{array}{l}\text { Persentase } \\
\text { Kelayakan }\end{array}$ & Kategori \\
\hline 1. & 12 & 9 & $75 \%$ & Tinggi \\
\hline 2. & 12 & 9 & $75 \%$ & Tinggi \\
\hline 3. & 8 & 6 & $175 \%$ & Tinggi \\
\hline 4. & 8 & 6 & $75 \%$ & Tinggi \\
\hline 5. & 4 & 3 & $75 \%$ & Tinggi \\
\hline 6. & 8 & 6 & $75 \%$ & Tinggi \\
\hline
\end{tabular}

Dari tabel 4 menunjukkan hasil validasi dari ahli media praktisi terhadap pengembangan media kereta membaca berbasis kontekstual learning siswa kelas 1 SD berkategori sangat tinggi dengan kelayakan sebesar $75 \%$ dari 7 aspek. Aspek yang divalidasi meliputi keterbacaan teks, kualitas gambar, keserasian warna, bentuk tekstur, bahan dan penggunaan media. Aspek Keterbacaan teks dari ahli media termasuk tinggi dengan mendapatkan kelayakan sebesar $75 \%$ dari 3 indikator. 3 Indikator ini mendapatkan penilaian setuju pada butir 1) ketepatan pemilihan warna, 2) ketepatan pemilihan jenis huruf, dan 3) indikator mendapatkan penilaian setuju yaitu indikator butir ke ketepatan pemilihan ukuran huruf Aspek Kualitas gambar berada pada kategori tinggi dengan kelayakan sebesar $75 \%$ dari 3 indikator. Setiap indikator dalam aspek ini memiliki kriteria tinggi. Indikator ini meliputi 1) Kejelasan bentuk gambar, 2) Ketepatan ukuran gambar, dan 3) Kejelasan warna gambar. Aspek keserasian warna memiliki kategori sangat tinggi dengan presentase 
324 Pengembangan Media Pembelajaran Kereta Membaca Berbasis Kontekstual Learning Siswa Sekolah Dasar - Shinta Herliana, Indri Anugraheni

75\%, Aspek ini memiliki 2 indikator yang masing - masing mendapatkan penilaian setuju yang meliputi, 1) ketepatan pemilihan warna pada background, 2) Keserasian warna tulisan dengan warna background. Aspek Bentuk memiliki tingat kelayakan tinggi dengan persentase $75 \%$ dari 2 indikator yang mendapatkan penilaian setuju yang meliputi 1) Ketepatan ukuran kartu kata bergambar, 2) Bentuk fisik kemasan media kereta membaca. Aspek Tekstur dengan kelayakan tinggi dengan presentase $75 \%$ dari 1 indikator yaitu keamanan bentuk permukaan media kartu kata bergambar untuk anak - anak. Aspek Bahan mendapatkan kelayakann tinggi dengan presentase $75 \%$ dari 2 indikator yang meliputi, 1) Ketepatan jenis kertas yang digunakan dalam media kereta membaca, 2) keawetan bahan yang digunakan pada media kereta membaca. Aspek penggunaan media mendapatkan kelayakan tinggi dengan persentase $75 \%$ dari 8 indikator meliputi 1) kejelasan buku petunjuk penggunaan kartu kata bergambar pada media kereta membaca, 2) kesesuaian kartu kata bergambar sebagai sumber belajar, 3) kemampuan kartu kata bergambar untuk dapat menciptakan rasa senang, 4) kemampuan kartu kata bergambar untuk alat bantu memahami dan mengingat informasi, 5) kesesuaian kartu kata bergambar dengan lingkungan belajar, 6) kemudahan, kartu kata bergambar dalam praktik pembelajaran, 7) kualitas kartu kata bergambar, 8) kepraktisan kartu kata bergambar. Adapun rata rata presentase hasil kelayakan dan validasi ahli praktisi materi dapat dilihat pada Tabel 5

\begin{tabular}{|c|c|c|c|c|}
\hline \multicolumn{5}{|c|}{ Tabel 5 Presentase Kelayakan Ahli Praktisi } \\
\hline Aspek & $\begin{array}{l}\text { Skor } \\
\text { Ideal }\end{array}$ & $\begin{array}{l}\text { Skor } \\
\text { Aktual }\end{array}$ & $\begin{array}{l}\text { Persentase } \\
\text { Kelayakan }\end{array}$ & Kategori \\
\hline 1. & 15 & 13 & $87 \%$ & $\begin{array}{l}\text { Sangat } \\
\text { Tinggi }\end{array}$ \\
\hline 2. & 20 & 16 & $80 \%$ & Tinggi \\
\hline 3. & 15 & 10 & $67 \%$ & Tinggi \\
\hline 4. & 10 & 6 & $60 \%$ & Cukup \\
\hline \multicolumn{3}{|c|}{$\begin{array}{c}\text { Rata - rata hasil } \\
\text { validasi ahli materi }\end{array}$} & $73 \%$ & Tinggi \\
\hline
\end{tabular}

Dari Tabel 5 menunjukkan bahwa hasil validasi ahli materi praktisi terhadap pengembangan media kereta membaca berbasis kontekstual learning siswa kelas 1 SD berkategori sangat layak dengan kelayakan sebesar $73 \%$. Aspek yang divalidasi meliputi relevansi, kesesuaian sajian dengan tuntutan pembelajaran yang terpusat pada siswa, cara penyajian, dan keterbacaan dan kekomunikasian. Aspek relevansi memiliki kelayakan sebesar $87 \%$ yang berkategori sangat tinggi. Aspek relevansi ini memiliki 3 indikator, indikator butir 1 mendapatkan penilaian baik, indikator butir 2 mendapatkan penilaian sangat baik, dan indikator butir 3 mendapatkan penilaian baik yang meliputi1) Materi relevan dengan kompetensi ang harus dikuasai siswa, 2) Kelengkapan uraian materi sesuai dengan tingkat perkembangan siswa, 3) Jabaran materi cukup memenuhi tuntutan kurikulum (Pelaksanaan literasi sesuai dengan permendikbud) Aspek Kesesuaian sajian dengan tuntutan pembelajaran yang terpusat pada siswa memiliki kelayakan sebesar $80 \%$ yang berkategori tinggi. 4 Indikator yang ada dalam aspek ini mendapatkan nilai baik. Indikator ini meliputi 1) Menyajikan kompetensi yang harus dikuasai siswa. 2) Mendorong keingin tahuan siswa untuk belajar mandiri menggunakan kereta membaca, 3) mendorong terjadinya interaksi siswa dengan sumber belajar kereta 
325 Pengembangan Media Pembelajaran Kereta Membaca Berbasis Kontekstual Learning Siswa Sekolah Dasar - Shinta Herliana, Indri Anugraheni

membaca, 4) mendorong siswa membangun pengetahuannya sendiri menggunakan kereta membaca. Aspek cara penyajian memiliki kelayakan sebesar $67 \%$ yang berkategori tinggi, Aspek ini memiliki 3 indikator, 1 indikator mendapatkan nilai baik dan 2 indikator mendapatkan nilai cukup. Indikator ini meliputi 1) Mendukung cara berpikir logis siswa menggunakan kereta membaca, 2) Ketepatan penggunaan ejaan kata, 3) Ketepatan penggunaan istilah kata. Aspek keterbacaan dan kekomunikasian yang memiliki kelayakan sebesar $60 \%$ yang berketegori cukup, aspek ini memiliki 2 indikator yang mendapatkan nilai cukup, indikator tersebut meliputi, 1) Panjang kata sesuai dengan tingkat pemahaman anak. 2) Struktur kata sesuai dengan pemhaman siswa.

Setelah merancang produk kemudian melakukan uji validasi terhadap media kereta membaca untuk meningkatkan literasi berbasis kontekstual leraning dan memperoleh hasil validasi dari ahli materi dengan skor $100 \%$ dan tergolong dalam interval $81-100 \%$ sehingga termasuk ke dalam kategori sangat tinggi. Dan mendapatkan saran dan masukan untuk menambahkan waktu yang dibutuhkan kedalam buku panduan, dan menambahkan catatan untuk guru dapat mengganti kartu kata sesuai dengan kebutuhan. Berdasarkan hasil dari validasi ahli media memperoleh skor $94 \%$ dan tergolong dalam interval $81-100 \%$ sehingga termasuk ke dalam kategori sangat tinggi, dan mendapatkan saran untuk menambahkan kata yang tidak bergambar dan diganti dengan benda konkret, untuk buku panduan ditambahkan halaman dan background yang sederhana. Hasil dari validasi materi oleh pengguna memperoleh skor $68 \%$ dan tergolong dalam interval $61-80 \%$ sehingga termasuk dalam kategori tinggi. Hasil dari validasi media oleh pengguna memperoleh skor $75 \%$ dan tergolong dalam interval $61-80 \%$ sehingga termasuk dalam kategori tinggi, dan mendapatkan masukan dan saran untuk bahan yang digunakan sudah cukup awet. Dari hasil uji validator ini sejalan dengan pernyataan Treacy, et.all dalam penelitian pada tahun 2012 yang berjudul The Effect Of Flash Card and Student Selected Reinforcers With Goals and Additional Practice With Multiplication Facts For Two Intermediate Elementary Student With Behavior Disorders yang menyatakan bahwa media pembelajaran flashcard berbasis gambar dapat meningkatkan minat dan ketertarikan siswa dalam pembelajaran. (Treacy et al., 2012) Apabila siswa secara terus menerus berlatih menggunakan media kereta membaca ketrampilan siswa dalam membaca atau literasi juga akan meningkat.

\section{SIMPULAN}

Penelitian ini menghasilkan produk berupa media pembelajaran media kereta membaca berbasis kontekstual learning. Yang dikembangkan dengan model ASSURE. Berdasarkan hasil dari uji validasi dari ketiga ahli yaitu ahli materi, media dan praktisi dapat dikatakan sangat layak untuk digunakan dalam kegiatan pembelajaran membaca dengan hasil presentase pengembangan media pembelajaran kereta membaca berbasis kontekstual learning kelas 1 SD layak untuk dapat digunakan dengan kelayakan sebesar $100 \%$ dari pakar materi yang berkategori sangat layak dengan saran untuk memberikan keterangan waktu disetiap sesi dalam buku pedoman, dan mendapatkan masukan memberikan catatan bahwa guru bisa menambah, atau mengubah kartu kata yang terdapat pada media kereta membaca sesuai kreatifitas guru. Dari ahli media mendapatkan kelayakan sebesar $97 \%$ dan mendapatkan kategori sangat layak dan medapatkan saran bahwa di gerbong kereta yang terakhir untuk menambahkan 
326 Pengembangan Media Pembelajaran Kereta Membaca Berbasis Kontekstual Learning Siswa Sekolah Dasar - Shinta Herliana, Indri Anugraheni

kartu puzzle yang tidak ada gambarnya dan menggunakan benda - benda konkret sebagai gantinya. Dari ahli praktisi mendapatkan kelayakan materi sebesar $73 \%$ dan media sebesar $75 \%$ dan mendapatkan kategori layak, dan mendapatkan komentar bahwa media kereta membaca berat untuk dibawa kemana - mana. Hasil Pretest yang dilakukan tanpa menggunakan media kereta membaca diperoleh rata - rata sebesar 33, $93 \%$. Hal ini menunjukkan bahwa pengembangan media pembelajaran kereta membaca terbukti layak dan dapat digunakan untuk kegiatan pembelajaran siswa SD kelas 1. Dalam penelitian dan pengembangan kereta membaca ini memiliki kekurangan yaitu media kereta membaca menggunakan bahan yang berat dan kurang praktis apabila dibawa kemana - mana, maka dari itu disarankan agar peneliti selanjutnya dapat memperhatikan bahan untuk mengembangkan media kereta membaca yang lebih baik.

\section{DAFTAR PUSTAKA}

Anugraheni, I. (2018). Pengembangan Perangkat Pembelajaran Matematika Berbasis Pendidikan Karakter Kreatif Di Sekolah Dasar. Refleksi Edukatika: Jurnal Ilmiah Kependidikan, https://doi.org/10.24176/re.v8i2.2351

Desi Indriyani1, Desyandri2, Yanti Fitria3, I. (2019). Pengaruh Media Kartu Kata Terhadap Kemampuan Membaca Permulaan Siswa Kelas 1 Sekolah Dasar. Jurnal Basicedu, 3(2), 524-532.

Fahyuni, E. F., \& Bandono, A. (2015). Pengembangan Media Cerita Bergambar Sebagai Upaya Meningkatkan Kemampuan Membaca Siswa Sekolah Dasar. Jurnal Kependidikan Dan Keislaman, 1-17.

Fridani, Lara; Dhieni, N. (2014). Hakikat Perkembangan Bahasa Anak. Metode Pengembangan Bahasa, 1-28.

Jaruki, M. (2008). Bahasa Kita Bahasa Indonesia.
Pusat Perbukuan Departemen Pendidikan Nasional.

Komalasari. (2010). Pembelajaran Kontekstual. PT Refika Aditama.

Mua`wanah E \& Hidayah R. (2009). No Title. In BimbingaknKonseling Islami di Sekolah Dasar (p. 7). Bumi Aksara.

Mudlofir, Rusidiyah E F, A. (2016). Desain Pembelajaran Inovatif Dari Teori ke Praktik. In Desain Pembelajaran Inovatif Dari Teori ke Praktik (p. 124). PT Raja Grafindo.

Nurseto, T. (2012). Membuat Media Pembelajaran yang Menarik. Jurnal Ekonomi Dan Pendidikan, $\quad 8(1), \quad 19-35$. https://doi.org/10.21831/jep.v8i1.706

Panjaitan, D. J. (2016). Meningkatkan Hasil Belajar Siswa dengan Metode Pembelajaran Langsung. Matchematics Pedagogic, 1, 83.

Pribadi, B. (2011). Model ASSURE Untuk mendesain Pembelajaran Sukses. Dian Rakyat.

Rahman, B., \& Haryanto, H. (2014). Peningkatan Keterampilan Membaca Permulaan Melalui Media Flashcard Pada Siswa Kelas I Sdn Bajayau Tengah 2. Jurnal Prima Edukasia, 2(2), 127. https://doi.org/10.21831/jpe.v2i2.2650

Smaldino. (2011). Instuctional Techonology an Media Learning. Kencana Prenada Media Group.

Treacy, R., Derby, K., McLaughlin, T., \& Schlettert, E. (2012). The effects of flashcards and student selected reinforcers with goals and additional practice with multiplication facts for two intermediate elementary students with behavior disorders. Academic Research International, 2(1), 469.

Wina Sanjaya. (2006). Strategi Pembelajaran berorientasi standar proses pendidikan. 